Volume 4 No. 4 Oktober 2019

p-ISSN: 2477-8192 dan e-ISSN: 2502-2776

\title{
POLA PERSEBARAN DAN KETERJANGKAUAN LOKASI SEKOLAH TERHADAP PEMUKIMAN DENGAN MENGGUNAKAN SISTEM INFORMASI GEOGRAFI KECAMATAN BATAUGA KABUPATEN BUTON SELATAN
}

\author{
Mukhlis $^{1}$, La Harudu \\ ${ }^{1}$ Jurusan Pendidikan Geografi \\ Universitas Halu Oleo \\ E-mail: mukhlis19@gmail.com \\ ${ }^{2}$ Jurusan Pendidikan Geografi \\ Universitas Halu Oleo \\ E-mail: laharudu@uho.ac.id
}

(Received: 2 September 2019 ; Accepted: 1 November 2019; Published: 1 November 2019)

(C)2019 - Jurnal Penelitian Pendidikan Geografi. Ini adalah artikel dengan

akses terbuka dibawah licenci CC BY-NC-4.0 (http://creativecommons.org/licenses/by-nc/4.0).

\section{ABSTRACK}

Schools are the main means of meeting the community's need for education. For this reason, schools must be located in strategic positions and spread evenly throughout the region. The purpose of this study was to determine the pattern of distribution of school locations in the District of Batauga, South Buton Regency and to know the affordability of school locations for settlements in the District of Batauga Buton Selatan. The method used in this research is descriptive quantitative method with Nearest Neighbor Analysis and baffer analysis. The data in this study were obtained by survey and document review. The results showed that; 1) the distribution pattern of School Locations in the Batauga Subdistrict is calculated using the analysis of the nearest neighbor (Analysis Nearest Nighbour) obtained T value $=0.26369$, the spatial pattern of the distribution of School Locations in the Batauga Subdistrict is a clustered Cluster, 2) the results of the spatial analysis using the Baffer function of the distribution of school locations in Batuaga District, have not fully served the entire Village / Kelurahan in the Batauga District. Junior high school education facilities (SMP /MTs) are only able to serve 75\%, namely Lawela Village, Lawela Seatan, Bandar Batauga, Busoa, Lakambau, Majapahit, Pogalampa, Mologina and Bola Village. While the Village / Kelurahan that have not been served by junior high school education facilities (SMP / MTs) are Masiri Village, Laompo Village and Lampanairi Village. While for high school (SMA) 91.6\% have served the entire village / kelurahan in Batuga sub-district. As for those who have not yet been reached by high school education facilities (SMA) is Mologina Village.

Keywords: Distribution Patterns, Affordability of School Locations, GIS.

\section{ABSTRAK}

Sekolah merupakan sarana utama dalam pemenuhan kebutuhan masyarakat akan pendidikan. Untuk itu sekolah harus terletak pada posisi yang strategis dan tersebar merata diseluruh daerah. Tujuan dalam penelitian ini adalah untuk mengetahui pola persebaran lokasi sekolah di Kecamatan Batauga Kabupaten Buton Selatan serta mengetahui keterjangkauan lokasi sekolah terhadap pemukiman di Kecamatan Batauga Buton Selatan. Metode yang digunakan dalam penelitian ini adalah metode deskriptif kuantititatif dengan 
Analisis Neighbour Nearest dan analisis baffer. Data dalam penelitian ini diperoleh dengan survei dan kajian dokumen. Hasil penelitian menunjukan bahwa; 1) pola persebaran Lokasi Sekolah di Kecamatan Batauga dihitung dengan menggunakan analisis tetangga terdekat (Analysis Nearest Nighbour) diperoleh nilai $T=0,26369$, pola spasial persebaran Lokasi Sekolah di Kecamatan Batauga adalah tersebar Mengelompok (Cluster pattern), 2) hasil analisis spasial menggunakan fungsi Baffer sebaran lokasi sekolah di Kecamatan Batuaga, sepenuhnya belum melayani seluruh Desa/Kelurahan yang ada di Kecamatan Batauga. Fasilitas pendidikan Sekolah Menengah Pertama (SMP/MTs) hanya mampu melayani $75 \%$ yaitu Desa Lawela, Lawela Seatan, Bandar Batauga, Busoa, Lakambau, Majapahit, Pogalampa, Mologina dan Desa Bola. Sedangkan Desa/Kelurahan yang belum terlayani Fasilitas pendidikan Sekolah Menengah Pertama (SMP/MTs) yaitu Desa Masiri, Desa Laompo dan Desa Lampanairi. Sementara untuk Sekolah Menengah Atas (SMA) 91,6\% telah melayani keseluruhan Desa/Kelurahan di Kecamatan Batuga. Adapun yang belum terjangkau oleh fasilitas pendidikan Sekolah Menengah Atas (SMA) adalah Desa Mologina.

Kata Kunci: Pola Persebaran, Keterjangkauan Lokasi Sekolah, SIG

\section{PENDAHULUAN}

Dasar kebijakan pendidikan nasional terkait dengan sebaran dan daya jangkauan pelayanan sekolah dapat ditelusuri dari amanat undang-undang Nomor 20 tahun 2003 tentang sistem pendidikan. Visi departemen pendidikan nasional adalah terwujudnya sistem pendidikan sebagai pranata sosial yang kuat dan berwibawa untuk memberdayakan semua warga Negara Indonesia berkembang menjadi manusia yang berkulaitas sehingga mampu dan proaktif menjawab tantangan zaman yang selalu berubah (Zainudin, 2015: 148).

Fasilitas pendidikan yang menjadi prioritas penunjang dalam melengkapi pemenuhan ketersediaan infrastruktur sosial disuatu permukiman harus terletak pada posisi yang strategis dan tersebar merata diseluruh daerah (Maesyaroh, 2010). Berdasarkan standarisasi nasional (2004), dasar penyediaan sarana pendidikan/sekolah ini juga mempertimbangkan pendekatan desain keruangan, unit-unit atau keompok lingkungan yang ada. Tentuya hal ini dapat terkait dengan bentukan grub bangunan/blok yang nantinya terbentuk berdasarkan kebutuhan dasar sarana yang harus dipenuhi untuk melayani pada era tertentu.

Letak Kecamatan Batauga dilihat dari peta Kabupaten Buton Selatan berada disebelah selatan daerah Pulau Buton.Secara geografis terletak di antara $5,29^{\circ}-5,59^{\circ} \mathrm{LS}$. Wilayah kecamatan Batauga secara keseluruhan adalah daratan pulau Buton Selatan dengan luas 75,83 $\mathrm{km}^{2}$ dan jumlah penduduk tahun 2016 sebanyak 15.579 jiwa. Secara administrasi kecamatan batauga pada tahun 2016 terdiri dari 12 desa (BPS Kecamatan Batauga 2018).

Kecamatan Batauga merupakan ibukota Kabupaten Buton Selatan yang tergolong paling berkembang, ditunjukan dengan aksesibilitas yang bagus, banyak terdapat sekolah dan fasilitas umum/publik yang lengkap serta letaknya yang berbatasan langsung dengan Kota Bau-Bau. Selain itu kemudahan untuk menjangkau akses sarana dan prasarana, kemudahan transportasi dan aksesibilitas menuju pusat kota Bau-Bau, sehingga pemukiman penduduk cenderung memanjang (linear) dengan jalan utama (Peraturan Menteri Pekerjaan Umum No. 41/PRT/M/2007).Terdapat beberapa ketentuan u mum dalam pemanfaatan kawasan permukiman, salah satu diantaranya adalah pemanfaatan dan pengelolaan kawasan pemukiman harus didukung oleh ketersediaan utilitas umum (jalan, drainase, air bersih, sanitasi, persampahan, jaringan listrik, dan jaringan telekomunikasi) dan fasilitas umum atau penunjang pemukiman (kesehatan, pendidikan, peribadatan). Salah satu pemukiman yang sangat dibutuhkan keberadaannya adalah fasilitas pendidikan/sekolah (Pancarrani, 2014: 66).

Penggunaan sistem informasi geografi (SIG) merupakan salah satu langkah untuk membantu pemerintah daerah kecamatan Batauga Kabupaten Buton Selatan.Dengan adanya sistem informasi (SIG) sebaran sekolah ini, selain membantu tersedianya sarana informasi bagi pemerintahan di Kecamatan Batauga. Sistem informasi geografi (SIG) juga berguna sebagai media analisa perencanaan dalam proses 
pembangunan peningkatan sarana dan prasarana pendidikan, karena sistem informasi geografi (SIG) mempunyai kemampua $\mathrm{n}$ analisis keruangan (spatial analysis) maupun waktu (temporal analysis) sehingga teknologi ini sering dipakai dalam proses perencanaan. Hasil akhirnya diharapkan mampu menjadi sarana informasi masyarakat dan rekomendasi pihak terkait untuk meningkatkan layanan pendidikan di wilayah Kecamatan Batauga.

\section{METODE PENELITIAN \\ Jenis Penelitian}

Penelitian ini menggunakan penelitian deskriptif kuantitatif dan evaluatif untuk mengidentifikasi pola persebaran spasial dan keterjangkauan lokasi sekolah terhadap pemukiman di wilayah Kecamatan Batauga, Kabupaten Buton Selatan.

\section{Lokasi Penelitian}

Penelitian ini dilaksanakan di Kecamatan Batauga, Kabupaten Buton Selatan, dan berlangsung dari bulan Januari sampai selesai.
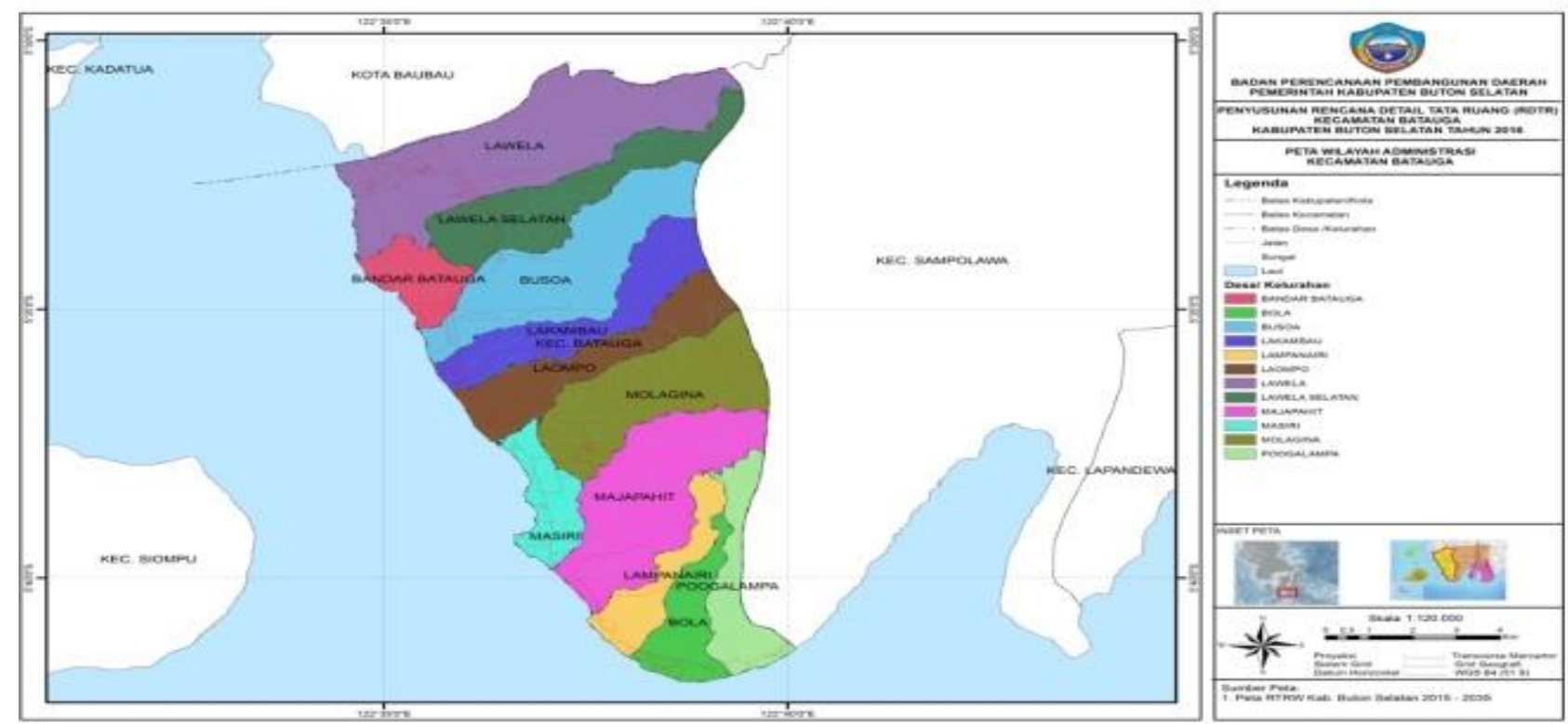

Gambar 1. Peta Administrasi Kecamatan Batauga, Kabupaten Buton Selatan

(BAPPEDA Buton Selatan 201).

\section{Populasi Penelitian}

Populasi dalam penelitian ini adalah seluruh fasilitas pendidikan yang berjumlah 42 Sekolah dari jenjang pendidikan pra sekolah (taman kanak-kanak), sekolah dasar (SD), sekolah lanjutan tingkat pertama (SLTP), dan sekolah lanjutan tingkat atas (SLTA) di Kecamatan Batauga Kabupaten Buton Selatan.

\section{Jenis dan Sumber Data}

Jenis data yang digunakan dalam penelitian ini adalah data spasial dan data atribut. Data spasial yang digunakan dalam penelitian adalah peta administrasi kecamatan Batauga yang diperoleh dari BAPPEDA atau Instansi terkait. Sedangkan data Atribut yang digunakan dalam penelitian ini adalah: Data Penduduk Kecamatan
Batauga, untuk mengetahui informasi umum lokasi survei dan pemetaan seperti letak geografis, banyaknya jumlah penduduk dikecamatan batauga, banyaknya jumlah Pendidikan formal.

\section{Metode Pengumpulan Data}

Teknik pengumpulan data ini dilakukan dengan observasi, studi kepustaan, dan studi dokumentasi. Observasi dilakukan dengan pengamatan langsung dilapangan yaitu seluruh unit sekolah. Kegiatan ini bermaksud untuk melihat keadaan kenampakn lokasi sekolah dengan pemberian titik tersebut menggunakan bantuan global posisition system (GPS), dan kemudian dilakukan plotting saat observasi dilapangan, hasil yang diperoleh dari GPS akan 
dilakukan pengelolaan dengan menggunakan software ArcGis 10.3 untuk memperoleh peta pola sebaran dan radius keterjangkauan fasilitas pendidikan/sekolah. Sedangkan studi kepustakaan adalah Pengumpulan data dari literatur-literatur dan dokumentasi dari internet, goole eart, SAS planet, dan sumber informasi lain,misalnya ; gambar-gambar denah dan peta.

\section{Teknis Analisis Data}

\section{Arc Gis.10.3}

Metode pengolahan data pada penyususnan Tugas Akhir ini dilakuakan dengan perangkat lunak ArcGis.10.3 merupakan perangkat lunak Geography Information System yang sangat popular dan paling banyak digunakan untuk mengelola data spasial sehingga data tersebut dianalisis dan dibuat peta serta laporan yang berkaitan dengan data spasial bereferensi geografis sehingga dihasilkan project, view, tabel, chart, layout dan script (Ria Awaliya, 2013 dalam Animsa, 2015).

\section{Analisis Tetangga Terdekat (Nearest Neighbour Analysis)}

Analisis tetangga terdekat merupakan salah satu analisis yang digunakan untuk menjelaskan pola persebaran dari titik-titik lokasi tempat dengan menggunakan perhitungan yang mempertimbangkan, jarak, jumlah titik lokasi dan luas wilayah dengan rumus yang digunakan dalam NNA (Nearest Nearest Neighbour Analysis) adalah sebagai berikut:

$$
\begin{aligned}
& T=\frac{J u}{J h} \\
& J u=\frac{\text { jumlah jarak }}{\text { jumlah titik }}
\end{aligned}
$$

$$
\begin{array}{ll}
J h= & \frac{1}{2 \sqrt{P}} \\
P= & \frac{\text { jumlah titik }}{\text { luas wilayah }} \\
\mathrm{T} \quad=\text { Indeks Penyebaran tetangga terdekat. } \\
\mathrm{Ju} \quad \begin{array}{l}
\text { = Jarak rata-rata yang diukur antara suatu } \\
\text { titik dengan tetangga terdekat. } \\
\text { = Jarak rata-rata yang diperoleh andaikata } \\
\text { semua titik mempunyai pola random. }
\end{array}
\end{array}
$$

\section{Buffer}

Buffer merupakan bentuk lain dari teknik analisis yang mengidentifikasi hubungan antara suatu titik dengan area di sekitarnya atau disebut sebagai Proximity Analysis (analisis faktor kedekatan). Proximity Analysis merupakan proses analisa yang biasa digunakan dalam penentuan site/lahan untuk keperluan strategi (Aqli, 2010).

\section{HASIL PENELITIAN}

\section{Analisis Pola Persebaran Lokasi Sekolah}

Pola persebaran lokasi sekolah dimaksudk an untuk menjelaskan secara keruangan persebar an seluruh sekolah di Kecamatan Batauga, Kabupaten Buton Selatan yang mengacu pada peta sebaran lokasi sekolah. Dalam analisis pola persebaran lokasi sekolah menggunakan analisis tetangga terdekat (nearest neighbour analysis), perlunya melakukan pemetaan lokasi-lokasi sekolah dengan bantuan Global Positioning System (GPS) untuk penentuan Kordinat tiap lokasi sekolah di kecamata Batauga. 


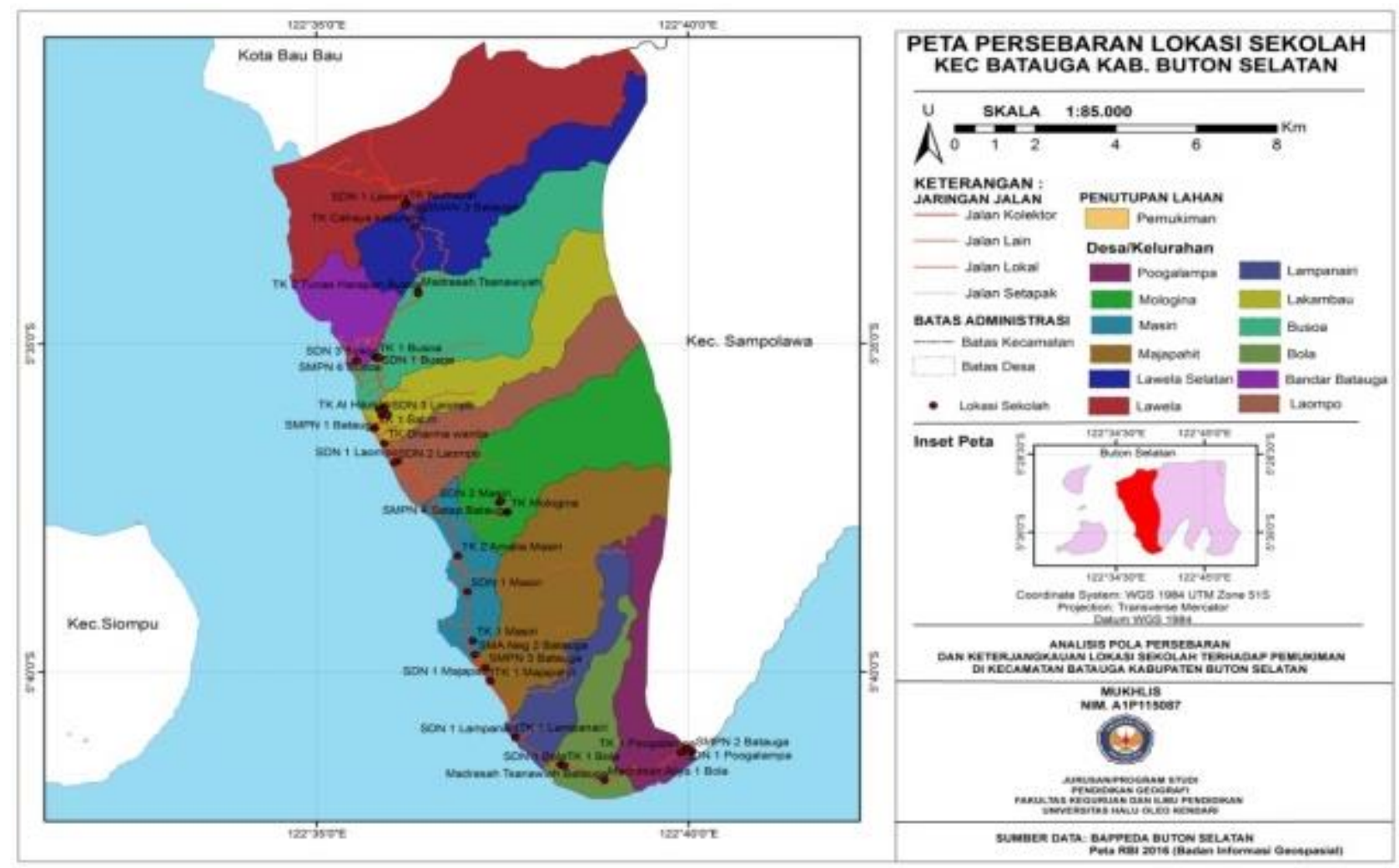

Gambar 2. Peta Persebaran Lokasi Sekolah Kecamatan Batauga Kabupaten Buton Selatan

Dari data dapat diketahui bahwa jumlah jarak dalam Km 8,313 Sedangkan luas wilayah Kecamatan Batauga 94,69 $\mathrm{Km}^{2}$ Sehingga perhitungan $\mathrm{T}$ adalah sebagai berikut:

1. Ju $=\frac{\text { Jumlah Jarak }}{\text { Jumlah } \text { Titik }}=\frac{8,313}{42}=0,197928$

2. $P=\frac{\text { Jumlah Titik }}{\text { Luas Wilayah }}=\frac{42}{94,69}=0,443552$

3. $\mathrm{Jh}=\frac{1}{2 \sqrt{\mathrm{P}}}$

$=\frac{1}{2 \sqrt{0,443552}}$

$=\frac{1}{2 \cdot 0,665996}$

$=\frac{1}{1,331992}=0,7507525$

4. $T=\frac{J u}{J h}=\frac{0,197928}{0,7507525}=0,26369$

Berdasarkan hasil perhitungan diatas menunjukan bahwa niali $\mathrm{T}$ persebaran lokasi sekolah di kecamatan Batauga, Kabupaten Buton Selatan adalah sebesar 0,26369. Hal ini menandakan bahwa pola perebaran lokasi sekolah di Kecamatan Batauga Kabupaten Buton Selatan adalah tersebar secara mengelompok (cluster pattern) karena mempunyai nilai $\mathrm{T}<1$.

\section{Analisis Jarak Jangkauan Lokasi Sekolah} Terhadap Pemukiman.

a) Berdasarkan pengamatan dilapangan dan hasil olahan spasial Baffer menggunakan Software ArcGis 10.3 ketersediaan taman kanak-kanak di kecamatan Batauga terdiri atas 15 unit tersebar dibeberapa Desa/Kelurahan yang berlokasi berdampingan dengan SD (sekolah dasar) ditengah pemukiman. Berdasarkan hasil analisis spasial dengan menggunakan fungsi buffer, seluruh wilayah desa di Kecamatan Batauga sudah terlayani fasilitas pendidikan sekolah Taman KanakKanak.

b) Jangkauan Pelayanan Berdasarkan standar Nasional Indonesia 13-1733-2004, pendidikan Sekolah Dasar memiliki radius jangkauan pelayanan dengan radius jangkauan sejauh 1000 meter $^{2}$. Kecamatan 
Batauga memiliki 13 fasilitas pendidikan SD (Sekolah Dasar) yang tersebar di seluruh Desa/Kelurahanhanya Desa Lawela Selatan belum tersedia fasilitas SD (Sekolah Dasar) namun telah terlayani oleh Fasilitas Sekolah SD dari Desa Lawela, karena masih terkena Radius Baffer Pelayanan di Kecamatan Batauga.

c) Hasil analisa data berdasarkan Analisis Baffer menunjukkan bahwa SMP/MTs yang terdiri dari 8 unit Fasilitas Pendidikan/Sekolah hanya mampu melayani 9 Desa/kelurahan sedangkan 3 Desa/kelurahan lainya belum terlayani. Hal ini berdasarkan Analisis Baffer besaran keterimaan pelayanan sekolah terhadap pemukiman ditiap Desa/Kelurahan yang ada di Kecamatan Batauga. Fasilitas Pendidikan/Sekolah SMP/MTs telah mampu melayani 9 Desa/Kelurahan sedangkan 3 Desa/kelurahan yang belum terkena dampak radius baffer layanan sekolah terhadap pemukiman Desa/Kelurahan di Kecamatan Batauga. Apabila dipresentasekan Fasilitas Pendidikan/Sekolah hanya dapat melayani $75 \%$ Desa/Kelurahan di kecamatan Batauga, Kabupaten Buton Selatan.

\section{Persentase $=$ \\ $\frac{\sum \text { skordata yang diperoleh }}{\sum \text { skortotal }} \times 100 \%$}

(Sumber :Ali, 1993 dalam Abidin 2015)

$$
\begin{aligned}
& =\frac{\text { Desa } / \text { Kelurahan yang Terlayani }}{\text { JumlahKeseluruhanDesa } / \text { Kelurahan }} \times 100 \% \\
& =\frac{9}{12} \times 100=75 \%
\end{aligned}
$$

d) Berdasarkan atas keterjangkauanya terhadap pemukiman menunjukkan bahwa SMA yang terdiri dari 6 unit Fasilitas Pendidikan/ Sekolah telah mampu melayani hampir seluruh Desa/Kelurahan di kecamatan Batauga hanya Desa/kelurahan Mologina,yang belum terkena dampak radius baffer layanan sekolah SMA terhadap pemukiman. Sehingga apabila dipresentasekan Fasilitas Pendidikan/Sekolah Menengah Atas hanya dapat melayani 91,6\% Desa/Kelurahan di kecamatan Batauga, Kabupaten Buton Selatann.

$$
\begin{aligned}
& \text { Persentase }= \\
& \frac{\sum \text { skor datay ang diperoleh }}{\text { Sskortotal }} \times 100 \% \\
& \text { (Ali, 1993; Abidin, 2015) } \\
& =\frac{\text { Desa } / \text { Kelurahan yang Terlayani }}{\text { JumlahKeseluruhanDesa } / \text { Kelurahan }} \times 100 \% \\
& =\frac{11}{12} \times 100=91,6 \%
\end{aligned}
$$

\section{PEMBAHASAN}

\section{Pola Persebaran Lokasi sekolah di Kecamatan Batauga}

Analisis spasial dengan pendekatan pola persebaran spasial menjadi aspek penting dalam penentuan pola spasial secara kuantitatif. Pengukuran menggunakan pen dekatan kuantitatif dengan berbantuan sistem informasi geografis (SIG), dalam hal ini adalah aplikasi ArcGis10.3 dapat dilakukan dengan analisis statistik berbasis jarak atau dapat disebut dengan analisis pola berbasis jarak. Metode yang digunakan dalam teknik ini yaitu analisis tetangga terdekat (Nearest Neighbor Analysis). Berdasarkan Penelitan yang dilakuakan dengan analisis NNA, (Nearest Neighbor Analysis) dengan bantuan software ArcGis 10.3. menunjukkan pola distribusi atau persebaran spasial lokasi sekolah di Kecamatan Batauga dik ategorikan kedalam pola mengelompok. Hasil analisis tetangga terdekat menunjukkan bahwa sekolah di Kecamatan Batauga, dengan 38 titik dengan nilai $\mathrm{T}=0,26369$ yang artinya menunjukkan pola Persebaran Lokasi Sekolah mengelompok (cluster pattern) karena mempunyai nilai $\mathrm{T}<1$.

\section{Keterjangkauan Lokasi Sekolah Terhadap Pemukiman di Kecamatan Batauga}

Faktor eksternal keterjangkauan pelayanan fasilitas pendidikan adalah data hasil intersect buffering jangkauan pelayanan dari tiap-tiap sekolah yang tersedia di kecamatan Batauga. Membuat buffer sesuai jarak yang sudah ditentukan. Buffer dilakukan pada tiap-tiap Fasilitas pendidikan/sekolah disetiap jenjang. Dengan cara pilih "ArcToolbox" $\rightarrow$ AnalysisTools $\rightarrow$ Proximity $\rightarrow \quad$ MultipleRing Buffer $\rightarrow$ ditampilkan kotak dialog Multiple Ring Buffer memasukan pada kolom input feature dengan file jenjang sekolah yang sudah disimpan. Setelah itu mengisi pada kolom output feature class dengan nama dan direktori penyimpanan 
hasil multi ring buffer. Kemudian masukan jarakjarak yang ditentukan sesuai dengan SNI 131733-2004 pilih $\rightarrow$ OK.

Hasil buffer jangkauan layanan sekolah dalam menganalisa faktor eksternal (sekolah yang terkena dampak radius layanan sekolah terhadap pemukiman di kelurahan lain). Faktor eksternal yang dimaksud adalah besaran keterimaan pelayanan sekolah dari luar, sehingga keterjangkauan yang dimaksud adalah melihat pemukiman ditiap kelurahan yang terjangkau oleh sekolah-sekolah yang ada di kecamatan Batauga. Sehingga dapat dikatakan pemukiman warga yang berada di dalam jangkauan pelayanan baffer tersebut yang berdasarkan standar Nasional Indonesia 13-1733-2004, merupakan daerah yang sudah terlayani fasilitas pendidikan Sekolah.

Bersadarkan analisis spasial buffering keterjangkauan taman kanak-kanak (TK) telah melayani seluruh desa dan kelurahan yang ada di Kecamatan Batauga. Bida dilihat dari Lokasi Sekolah TK dan pelayanan sekolah di Kecamatan Batauga. Sementara SMP/MTs di kecamatan Batauga hanya $75 \%$ yang melayani setiap pemukiman dimasing-masing desa/kelurahan. Desa/kelurahan yang belum terlayani dan terjangkau, karena berada diluar radius jangkauan pelayanan sekolah. Sementar SMA/SLTA sedera jat memiliki radius jangkauan pelayanan tertentu dengan radius jangkauan sejauh 3000 meter. Kecamatan Batauga memiliki 6 fasilitas pendidikan sekolah menengah atas yang tersebar di empat desa yakni untuk SMAN 1 Batauga dan SMK Al Safitri berloksi di Desa Lakambau, SMAN 2 Batauga, berlokasi di Desa Masiri, sementara Madrasah Aliya 1 berlokasi di Desa Bola sedangkan SMK Negeri 1 Batauga, berlokasi di Desa Poogalampa dan SMAN 3 Batauga berlokasi di Desa Lawela Selatan. Keempat fasilitas pendidikan tersebut harus menjangkau 12 wilayah Desa/Kelurahan yang ada di kecamatan Batauga. Berdasarkan hasil analisis spasial dengan menggunakan fungsi buffer, seluruh wilayah desa di kecamatan Batauga sudah 91,6\% terlayani oleh fasilitas pendidikan SMA/SLTA (sekolah menengah atas). Adapun pemukiman desa yang belum terlayani fasilitas pendidikan sekolah SMA/SLTA adalah desa Mologina (berada di luar radius jangkauan pelayanan fasilitas pendidikan sekolah).

\section{KESIMPULAN}

Dari hasil dan pembahasan yang sudah dipaparkan diatas dapat ditarik kesimpulan bahwa: pola persebaran Lokasi Sekolah di Kecamatan Batauga dihitung dengan menggunakan analisis tetangga terdekat (Analysis Nearest Nighbour) diperoleh nilai $\mathrm{T}=0,26369$, pola spasial persebaran Lokasi Sekolah di Kecamatan Batauga adalah tersebar Mengelompok (Cluster pattern), hasil analisis spasial menggunakan fungsi Baffer sebaran lokasi sekolah di Kecamatan Batuaga, sepenuhnya belum melayani seluruh Desa/Kelurahan yang ada di Kecamatan Batauga. Fasilitas pendidikan Sekolah Menengah Pertama (SMP/MTs) hanya mampu melayani $75 \%$ yaitu Desa Lawela, Lawela Seatan, Bandar Batauga, Busoa, Lakambau, Majapahit, Pogalampa, Mologina dan Desa Bola. Sedangkan Desa/Kelurahan yang belum terlayani Fasilitas pendidikan Sekolah Menengah Pertama (SMP/MTs) yaitu Desa Masiri, Desa Laompo dan Desa Lampanairi. Sementara untuk Sekolah Menengah Atas (SMA) 91,6\% telah melayani keseluruhan Desa/Kelurahan di Kecamatan Batuga. Adapun yang belum terjangkau oleh fasilitas pendidikan Sekolah Menengah Atas (SMA) adalah Desa Mologina.

\section{SARAN}

Untuk pemerintah Kecamatan Batauga Buton Selatan, Kesesuain lokasi gedung sekolah meskipun tidak menjadi masalah bagi penduduk untuk bersekolah di sekolah tersebut, tapi sebaiknya pembangunan sekolah didirikan pada tempat yang dianggap sesuai pada lokasi yang akan dibangun sekolah. Hal ini agar memudahkan penduduk untuk menuju ke sekolah tersebut. Penambahan sekolah SMP/MTs dan SMA di Kecamatan Batauga Sangat dibutuhkan untuk memenuhi kebutuhan penduduk usia sekolah di Kecamatan Batauga Kabupaten Buton Selatan.Penambahan Sekolah di Kecamatan Bata uga harus memperhatikan lokasi yang tepat guna menghindari penumpukan pelayanansehingga dapat menjangkau seluruh $\mathrm{D}$ esa/Kelurahan di Kecamatan Batauga Kabupaten Buton Selatan. 


\section{UCAPAN TERIMA KASIH}

Selama menyelesaikan penyusunan skripsi ini penulis telah menerima banyak bantuan dari berbagai pihak, baik secara langsung maupun tidak langsung. Oleh karena itu, pada kesempatan ini, terima kasih penulis sampaikan kepada pembimbing I Drs. La Harudu, M.Si serta kedua orang tua yang selalu memberikan kasih sayang, doa serta dorongan moril maupun materil yang tak terhingga, semoga selalu dalam lindungan Allah SWT.

\section{DAFTAR PUSTAKA}

Animsa, D.R dan Aeri Rachmad. (2015). Aplikasi Pemetaan Kantor Dinas Di Kabupaten Bangkalan-Madura Berbasis Android. Jurnal Sistem Informasi. Vol 2(2):24.

Aqli, Wafirul. (2014). Analisa Buffer Dalam Sistem Informasi Geografis Untuk Perencanaan Ruang Kawasan. Jurnal Inersia. Vol (2): 195.
BPSKecamatan Batauga. (2018). BPS Kecamatan Batauga Dalam Angka 2018. Buton Selatan

Maesyaroh, S. (2010). Implementasi Algoritma Topsis Dalam Pemelihan Dan Penentuan Kompetensi Asisten Laboratorium Di Fkom Uniku. Jurnal Buffer Informatika.Vol 4(1), 2010.

Pancarrani, G.P., dan Pigawati B. (2014). Evaluasi Kesesuaian Lokasi Dan Jangkauan Pelayanan Sekolah Menengah Umum di Kecamatan Kebakkramat Kabupaten Karanganyar. Jurnal Geoplanning. Vol. 1 (2):66.

Undang-Undang Negara Kesatuan Republik Indonesia No. 20 tahun 2003 tentang Sistem Pendidikan Nasional

Zainudin, M. (2015). Daya jangkau Siswa Ke Smp Negeri 1 Padangan Kabupaten Bonjonegoro Provinsi Jawa Timur.Jurnal geografi dan Pengajaran. Vol. 13(2): 148. 